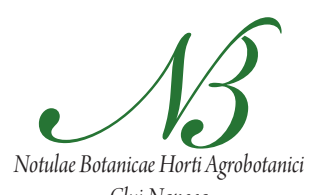

Cluj-Napoca

\title{
Does Primula intricata Gren. et Godr. Merit Species Rank? A Taxonomic Revision Based on nrDNA, cpDNA and AFLP Data
}

\author{
Dana ŞUTEU ${ }^{1}$, Mihai PUŞCAŞ ${ }^{2}$, Ioan BĂCILĂ ${ }^{1}$, Ana COSTE ${ }^{1}$ Liviu FILIPAŞ ${ }^{1}$, Ilie- \\ Adrian STOICA ${ }^{1}$, Bogdan-Iuliu HURDU ${ }^{1,3}$, Tudor URSU' ${ }^{1}$, Gheorghe COLDEA ${ }^{1}$ \\ ${ }^{1}$ National Institute of Research and Development for Biological Sciences, Institute of Biological Research Cluj-Napoca, \\ Department of Taxonomy and Ecology, 48 Republicii, RO-400015Cluj-Napoca, Romania; suteudana@yahoo.com \\ ${ }^{2}$ Babeş-Bolyai University, A. Borza Botanical Garden, 42 Republicii, RO-400015 Cluj-Napoca, Romania \\ ${ }^{3}$ Babeş-Bolyai University, Faculty of Biology and Geology, Department of Taxonomy and Ecology, 42 Republicii, RO-400015 Cluj-Napoca, Romania
}

\begin{abstract}
Primula intricata Gren. et Godr. has an unclear taxonomic status: it was originally described as a distinct species but subsequently was considered a subspecies (Primula elatior subsp. intricata) or even a variety (P. elatior var. intricata) of Primula elatior (L.) Hill. No prior genetic studies were performed on this group of Primulaceae, therefore we considered useful to investigate taxonomies boundaries within the $P$. elatior-intricata group. We explored genetic differences between Primula intricata and Primula elatior group by applying three different types of molecular markers: nuclear ribosomal DNA (ITS1), chloroplast DNA (spacer $\operatorname{trn} H$-psbA and intron trnL) and Amplified Fragment Length Polymorphisms (AFLP). We found a solid differentiation between $P$. intricata and $P$. elatior group, differentiation that was confirmed by all the employed molecular markers. This finding enabled us to propose a valid species rank for Primula intricata, as a separate taxon from the P. elatior group.
\end{abstract}

Keywords: AFLP, cpDNA, ITS, Primulaceae, taxonomy

\section{Introduction}

Primula intricata Gren. et Godr. belongs to subgenus Primula L. which is characterized by rosettes shoots, leaves hairy and revolute vernation (Valentine and Kress, 1972). The species is confine to upper mountain-subalpine moist grassland and it has a distribution restricted to South and Central part of Europe (Smith and Fletcher, 1946; Valentine and Kress, 1972).

P. intricata was originally described by Grenier and Godron (1853) from the Eastern Pyrenees as a distinct species with the following morphological features: leaves finely pubescent on both sides, oblong, obtuse, gradually narrowed into a long petiole and with a broad wing becoming obsolete below; scape, pedicels and the calyx with a fine tomentum. Subsequently Pax and Knuth (1889) reconsidered the taxonomic rank of $P$. intricata and ascribed it to $P$. elatior group (P. elatior var. intricata (Gren. et Godr.) Pax. Lüdi (1927) considered P. intricata as a distinct subspecies within the P. elatior group (Primula elatior (L.) Hill subsp. intricata (Gren. et Godr.) Lüdi) and this opinion is maintained by Valentine and Kress (1972) in Flora Europaea. According to Flora Euroapaea, P. intricata can be differentiated from $P$. elatior subsp. elatior by the leaves gradually narrowing into petiole and the capsule tapering markedly (Valentine and Kress, 1972).

Many taxonomical issues, especially where the morphological boundaries between very close taxa are scarce, were elucidated with the development of molecular markers (Foggi et al., 2006; Ishida et al., 2003; Lihová et al., 2004; Manoko et al., 2007; Muratović et al., 2005; Schönswetter et al., 2004; Schönswetter et al., 2009).

The main goal of this study was to investigate whether there is a genetically sound basis for supporting $P$. intricata as a distinct species from $P$. elatior $\mathrm{s}$. str. and to investigate the taxonomic boundaries between $P$. intricata and $P$. elatior group.

\section{Materials and methods}

\section{Sampling strategy}

In order to investigate the relationship between Primula intricata and Primula elatior group, we sampled seven populations from the Carpathians and the Alps (Fig. 1, Tab. 1) as follows: five populations of Primula elatior, one population of Primula elatior subsp. leucophylla and one population of Primula elatior subsp. intricata. Young, green leaves of five random individuals were collected for each population and stored in silica gel. Voucher specimens of all populations were deposited in CL Herbarium (Babeş-Bolyai University, Cluj-Napoca). Only for cpDNA and ITS sequences analysis we added one herbarium sample of Primula elatior subsp. intricata from Carpathians (Piatra Craiului Massif, CL no 510241) and two samples of Primula veris and $P$. acaulis as outgroups. 


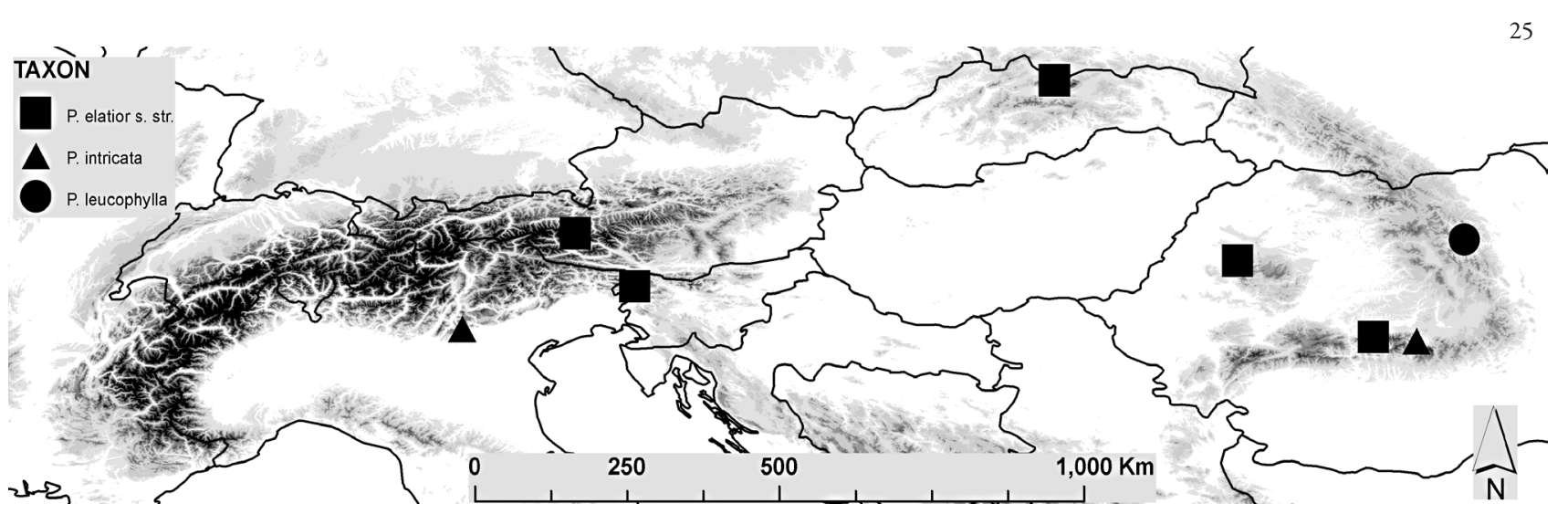

Fig. 1. Location of the populations of Primula sp. sampled for molecular analysis

\section{DNA extraction and AFLP protocol}

Total DNA was extracted from roughly $13 \mathrm{mg}$ of silica gel dried leaf tissue using DNeasy 96 Plant Mini Kit (Qiagen) according to the manufacturer's protocol, excepting the final elution which took place in $80 \mu \mathrm{l}$ in order to increase the DNA concentration. Three random individuals from the total sample set were extracted twice as blind samples (Bonin et al., 2004). The herbarium sample was extracted using a modified CTAB method of Doyle and Doyle (1987).

The AFLP protocol (based on Vos et al., 1995) followed the basic lines of Puşcaş et al. (2008) with minor modifications. Double digestion of genomic DNA was performed for two hours at $37^{\circ} \mathrm{C}$ in a $20 \mu \mathrm{l}$ mix using $2 \mathrm{U}$ of $M$ se I and $5 \mathrm{U}$ of EcoRI (Fermentas). Specific adapters were ligated to DNA in a $40 \mu \mathrm{l}$ volume for $2 \mathrm{~h}$ at $37^{\circ} \mathrm{C}$ using $1 \mathrm{U}$ of T4 DNA Ligase (Fermentas). Diluted $10 \mathrm{X}$, digested and ligated DNA was subjected to a preselective amplification using primers EA (5'-GACTGCGTACCAATTCA-3') and MC (5'-GATGAGTCCTGAGTAAC-3') in a $25 \mu \mathrm{l}$ volume containing $1 \mathrm{X}$ Buffer, $1.5 \mathrm{mM} \mathrm{MgCl}, 200 \mu \mathrm{M}$ of each dNTP, $0.2 \mu \mathrm{M}$ of each primer and 0.5 $\mathrm{U}$ of AmpliTaq DNA Polymerase (Applied Biosystems). Diluted 20 X, preselective products underwent selective amplification with the following primer combinations: EACC-MCAA, EACC-MCAT and EACT-MCAT (Jacquemyn et al., 2009). Selective amplifications took place in a $12.5 \mu \mathrm{l}$ volume containing $1 \mathrm{X}$ Buffer, $2.5 \mathrm{mM} \mathrm{MgCl}, 200 \mu \mathrm{M}$ of each dNTP, $0.2 \mu \mathrm{M}$ of each primer and $0.5 \mathrm{U}$ of AmpliTaq Gold $^{\circ}$ DNA Polymerase (Applied Biosystems). Following this step, excess labelled primers were removed by purification with Sephadex and Sephacryl (1:1) (GE Healthcare Bio-Sciences AB). Finally, $1.5 \mu$ l of diluted $(50 \mathrm{X})$ purification was added to a $10 \mu \mathrm{l}$ mixture (10:0.1) of $\mathrm{HiDi}$

Tab. 1. Location (mountain system, Massif), altitude and genetic diversity parameters (revealed by AFLP analyses) of the sampled populations of Primula sp.

\begin{tabular}{|c|c|c|c|c|c|c|c|c|}
\hline $\begin{array}{l}\text { Loc. } \\
\text { Nr. }\end{array}$ & Designate taxa & $\begin{array}{l}\text { Mountain } \\
\text { System }\end{array}$ & Massif & Location name & $\begin{array}{l}\text { Altitude } \\
\text { (m) }\end{array}$ & $\begin{array}{c}\text { Proportion } \\
\text { of variable } \\
\text { markers }\end{array}$ & $\begin{array}{c}\text { Gene } \\
\text { Diversity }\end{array}$ & Rarity \\
\hline 1 & $\begin{array}{l}\text { Primula elatior (L.) } \\
\text { Hill subsp. elatior }\end{array}$ & Alps & $\begin{array}{l}\text { Glocknergruppe } \\
\text { Alpen }\end{array}$ & $\begin{array}{c}\text { Grossglockner } \\
\text { Hochalpenstrasse }\end{array}$ & 2000 & 0.286 & 0.146 & 3.766 \\
\hline 2 & $\begin{array}{l}\text { Primula elatior (L.) } \\
\text { Hill subsp. elatior }\end{array}$ & Alps & Julian Alps & Soca Valley & 1750 & 0.133 & 0.061 & 2.804 \\
\hline 3 & $\begin{array}{l}\text { Primula elatior (L.) } \\
\text { Hill subsp. elatior }\end{array}$ & $\begin{array}{l}\text { Western } \\
\text { Carpathians }\end{array}$ & West Tatra & Kobylarzowy Żleb & 1650 & 0.267 & 0.132 & 5.503 \\
\hline 4 & $\begin{array}{l}\text { Primula elatior (L.) } \\
\text { Hill subsp. elatior }\end{array}$ & $\begin{array}{l}\text { South-Eastern } \\
\text { Carpathians }\end{array}$ & Vlădeasa & Stâna de Vale & 1096 & 0.235 & 0.113 & 3.279 \\
\hline 5 & $\begin{array}{l}\text { Primula elatior (L.) } \\
\text { Hill subsp. elatior }\end{array}$ & $\begin{array}{l}\text { South-Eastern } \\
\text { Carpathians }\end{array}$ & Făgăraş Mts. & Netedu & 2250 & 0.21 & 0.103 & 5.155 \\
\hline 6 & $\begin{array}{c}\text { Primula elatior (L.) Hill } \\
\text { subsp. leucophylla (Pax) } \\
\text { Hesl.-Harr.f. ex W.W.Sm. } \\
\text { et H.R.Fletcher }\end{array}$ & $\begin{array}{l}\text { South-Eastern } \\
\text { Carpathians }\end{array}$ & Ceahlău & Toaca & 1812 & 0.146 & 0.072 & 2.885 \\
\hline 7 & $\begin{array}{l}\text { Primula elatior (L.) Hill } \\
\text { subsp. intricata (Gren. } \\
\text { et Godr.) Lüdi }\end{array}$ & Alps & $\begin{array}{c}\text { Alpi } \\
\text { dell'Adamello e } \\
\text { della Presanella }\end{array}$ & Passo di Campo & 1470 & 0.133 & 0.068 & 8.005 \\
\hline 8 & $\begin{array}{l}\text { Primula elatior (L.) Hill } \\
\text { subsp. intricata (Gren. } \\
\text { et Godr.) Lüdi* }\end{array}$ & $\begin{array}{l}\text { South-Eastern } \\
\text { Carpathians }\end{array}$ & Piatra Craiului & Turnu & 1900 & - & - & - \\
\hline
\end{tabular}

* this sample was used only for cpDNA and ITS analyses 
26

formamide and GeneScan 500 ROX (Applied Biosystems). The purified PCR products were migrated on ABI PRISM $^{\circ} 3130$ Genetic Analyzer (Applied Biosystems) using a $36 \mathrm{~cm}$ capillary and POP $7^{\mathrm{TM}}$ polymer. The sizecalibrated genescan files were imported into GeneMapper v.4.0 (Applied Biosystems) for scoring. Fragments within the 50-500 bp range were scored to produce a present/ absence matrix.

\section{cpDNA and nrDNA protocol}

One nuclear region (ITS1) and two chloroplast DNA regions (the intergenic spacer $\operatorname{trnH}-p s b A$ and the intron $\operatorname{trn} L$ ) were used in the present study. The nuclear ribosomal DNA was amplify using primers ITS2 and ITS5 (White et al., 1990). The chloroplast region trnH-psbA was amplified using the primers $\operatorname{trn} \mathrm{H}^{\mathrm{GUG}}$ and psbA (described by Shaw et al., 2005). For amplifying the $t r n L$ region the following primers were used: trnLc and trnLd (Taberlet $e t$ al., 1991).

Amplifications were performed in a $50 \mu$ total reaction volume with 1X Taq Buffer, $2.5 \mathrm{mM} \mathrm{MgCl}, 0.5 \mathrm{mM}$ of each dNTP, $0.12 \mu \mathrm{M}$ of each primer, $0.16 \mathrm{mg} / \mathrm{ml} \mathrm{BSA}$, $2 \mathrm{U}$ of Dream Taq Polimerase (Fermentas) and $10 \mu \mathrm{l}$ of diluted genomic DNA. The amplification conditions for trnH-psbA were the ones mentioned in Shaw et al. (2005), with the annealing temperature of $55^{\circ} \mathrm{C}$. For $\operatorname{trnL}$ the amplification conditions were the following: $94^{\circ} \mathrm{C}, 3 \mathrm{~min} ; 35$ $x\left(94^{\circ} \mathrm{C}, 45 \mathrm{~s} ; 56^{\circ} \mathrm{C}, 45 \mathrm{~s} ; 72^{\circ} \mathrm{C}, 1 \mathrm{~min}\right) ; 72^{\circ} \mathrm{C}, 10 \mathrm{~min}$. The nrDNA ITS 1 had the following parameters: $94^{\circ} \mathrm{C}, 5$ $\min ; 35 \mathrm{x}\left(94^{\circ} \mathrm{C}, 1 \mathrm{~min} ; 52^{\circ} \mathrm{C}, 45 \mathrm{~s} ; 72^{\circ} \mathrm{C}, 2 \mathrm{~min}\right) ; 72^{\circ} \mathrm{C}$, $10 \mathrm{~min}$.

PCR products were purified by gel purification using Wizard $^{\mathrm{R}}$ SV Gel and PCR Clean-Up System, according to the manufacturer's protocol (Promega). Sequencing was performed in a $20 \mu \mathrm{l}$ volume using BigDye Terminator Cycle Sequencing Ready Reaction Kit, v. 3.1 according to the manufacturer's suggestions (Applied Biosystems), using the following thermal cycle parameters $96^{\circ} \mathrm{C}, 10 \mathrm{~s} ; 35$ $\mathrm{x}\left(96^{\circ} \mathrm{C}, 10 \mathrm{~s} ; 60^{\circ} \mathrm{C}\right.$ for ITS1, trnL and $50^{\circ} \mathrm{C}$ for trnH-ps$b A, 10 \mathrm{~s} ; 66^{\circ} \mathrm{C}, 4 \mathrm{~min}$. Both DNA strands were sequenced. Excess primers and labeled ddNTPs were removed by purification with Sephadex and Sephacryl (1:1) (GE Healthcare Bio-Sciences $\mathrm{AB}$ ). The samples were prepared prior sequencing by adding $10 \mu \mathrm{l}$ of $\mathrm{HiDi}$ formamide. The samples were run on an ABI PRISM 3130 Genetic Analyzer, Applied Biosystems.Sequences were assembled and edited using BioEdit v.7.0.9.0 (Hall, 1999).

\section{Data analysis}

For the AFLP dataset, the total number of AFLP bands, the proportion of polymorphic loci within each population, Nei's gene diversity (Nei, 1987) and the rarity index (corresponds to the frequency down weighed marker value proposed by Schönswetter and Tribsch, 2005) were estimated using AFLPdat R-script (Ehrich, 2006). A neighbor joining tree using Nei and Li's distance (Nei and $\mathrm{Li}, 1979)$ measure was constructed with Splistree v. 4.10 (Huson and Bryant, 2006). Bootstrap values were obtained with 1000 replicates.

Analysis of molecular variance (AMOVA), with partition of the total genetic variance into different levels (within populations, among populations, among groups of populations), were done with ARLEQUIN version 3.5 (Excoffier and Lischer, 2010).

Principal Coordinate Analysis (PCoAs) based on between-individual Jaccard similarities (Jaccard, 1901) were carried out by using the ADE- 4 software package (Thioulouse et al., 1997).

The relationships among detected cpDNA haplotypes were analyzed using the program Mega 4.1 (Tamura et al., 2007). The tree construction was made using Neighbor Joining method, based on Kimura's (1980) genetic distance.

\section{Results and discussions}

\section{AFLP data}

Using three pairs of primers, 236 scorable fragments have been generated, of which $212(89.8 \%)$ were polymorphic. The length of fragments ranged from 54 to 456 bp. The repeatability of AFLP results was high ( $97.92 \%$ for the overall test). The final matrix consisted of 35 individuals and 157 unambiguous polymorphic markers.

Analysis of molecular variance based on AFLP data was initially performed on Primula sp. populations without defining any groups. The percentage of variation was very high among populations (67.70, data not shown). A second AMOVA was performed after defining three groups corresponding to the three taxa: P. elatior, P. leucophylla and P. intricata (Tab. 2).

The highest amount of genetic variation in the sampled populations was found among groups (Tab. 2, AMOVA $43.96 \%$ overall populations) and suggests that the groups are well differentiated, with relative low gene flow within. The variation among populations within groups is also relatively high. This result might be due to an inner structure

Tab. 2. Results of analysis of molecular variance (AMOVA) based on the AFLP matrix with three defined groups

\begin{tabular}{ccccc}
\hline Source of variation & d.f & Sum of squares & Variance components & Percentage of variation \\
\hline Among groups & 2 & 320.937 & $13.47673 \mathrm{Va}$ & 43.96 \\
Among populations within groups & 4 & 218.320 & $9.35029 \mathrm{Vb}$ & 30.50 \\
Within populations & 28 & 219.200 & $7.82857 \mathrm{Vc}$ & 25.54 \\
Total & 34 & 758.457 & 30.65558 & \\
\hline
\end{tabular}




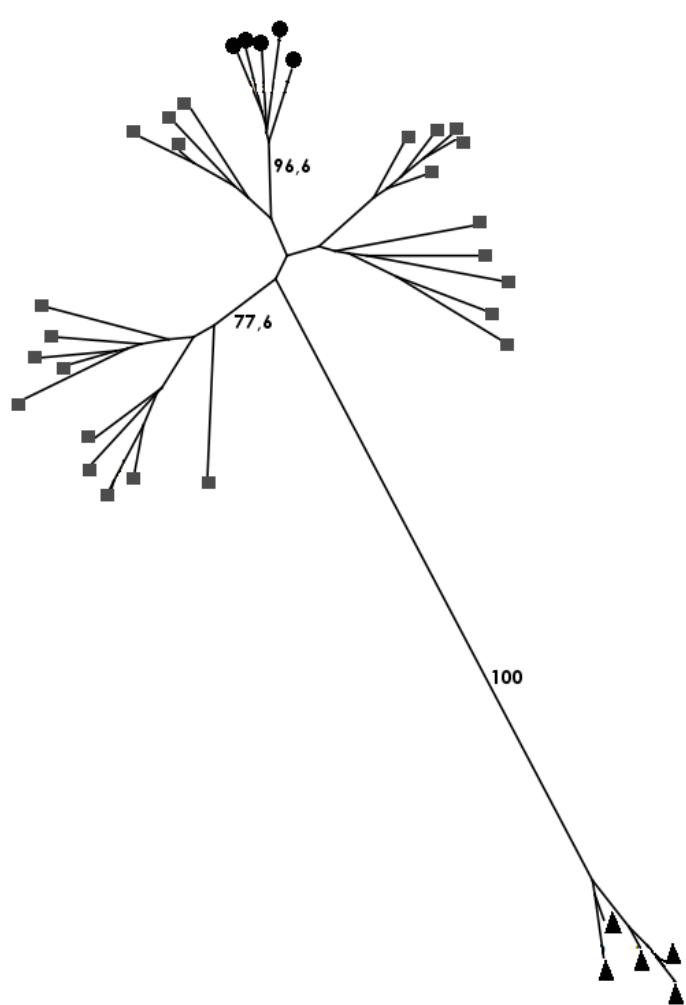

Fig. 2. Neighbor Joining analysis based on the AFLP data. Symbols are the same as in Fig. 1 within groups based on geographical criteria (the three populations of $P$. elatior were collected from distant localities from South-Eastern Carpathians, Western Carpathians and Alps).

When referring to gene diversity, proportion of variable markers and rarity, the highest genetic diversity and the highest proportion of variable markers were found in one population from the Alps (Glocknergruppe Alpen) while the population of Primula intricata was among the poorest. However, the population of Primula intricata harbors the highest number of private markers, once again showing its high differentiation from the P. elatior group.

In the Neighbor-Joining analysis, two major phylogroups were separated with maximum bootstrap support. One group is represented by the population of Primula intricata from the Alps and the second group is composed by the populations of Primula elatior and Primula leucophylla (Fig. 2). The Alpine population of Primula intricata falls into a clearly divergent group, this is most straightforwardly observed in branch lengths and bootstrap support values of the $\mathrm{NJ}$ tree.

The PCoA of the AFLP matrix of analyzed individuals confirms approximately the same phylogeographical pattern with two main groups: the population of Primula intricata from the Alps clearly differentiated from the second group containing the populations of $P$. elatior and $P$. leucophylla ( Fig. 3).

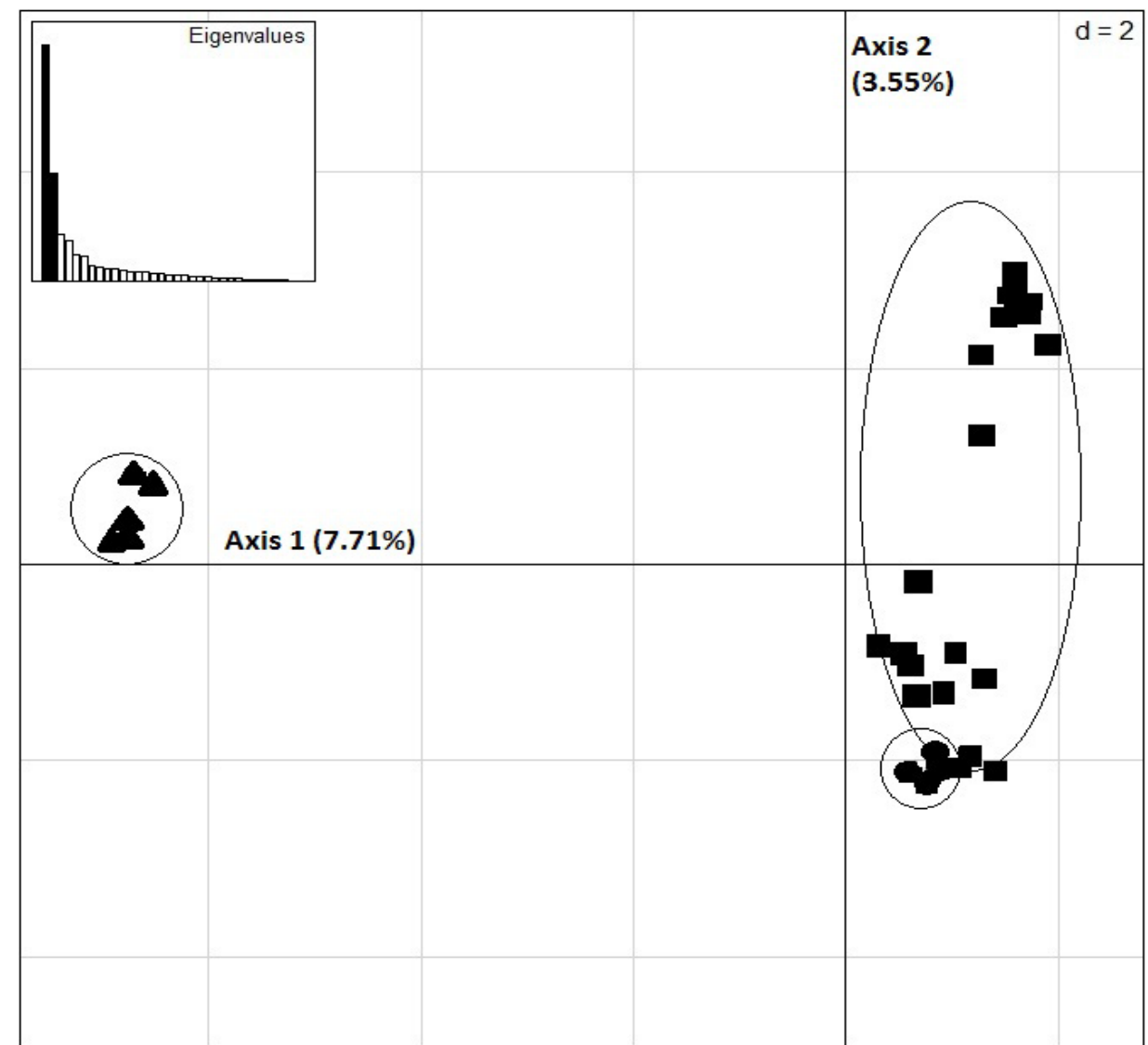

Fig. 3. Results of the Principal Coordinate Analysis (PCoA) based on AFLP data, symbols are the same as in Fig. 1 


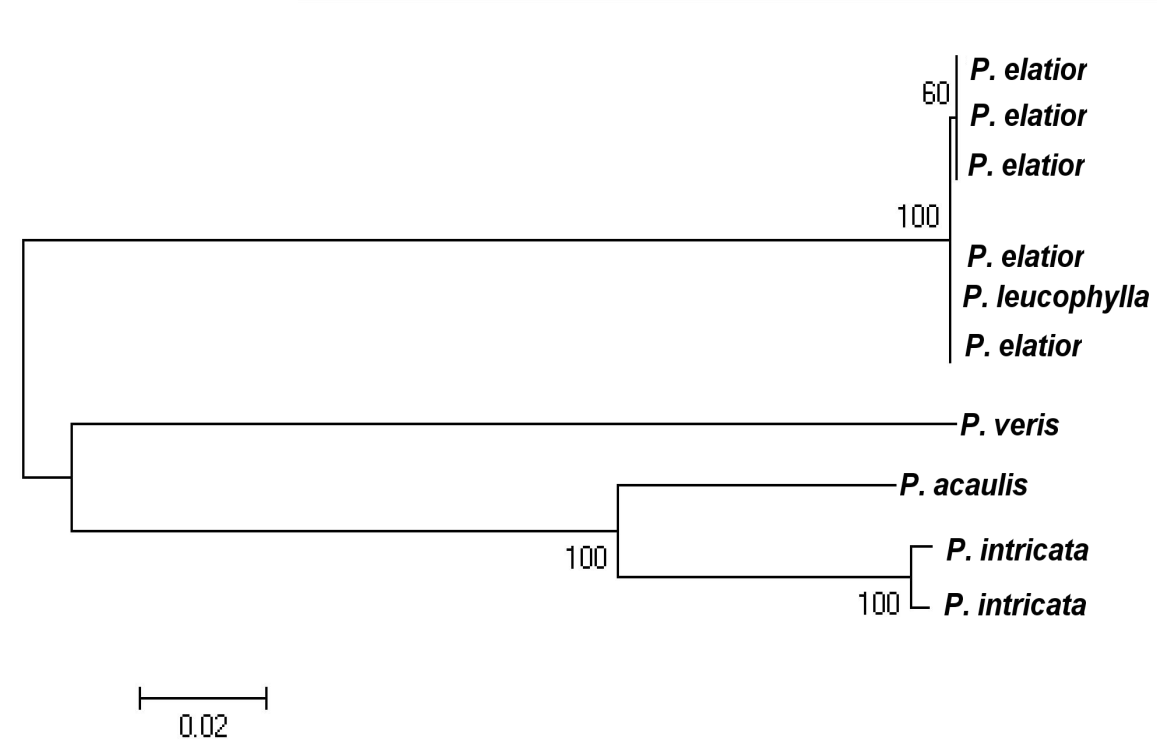

Fig. 4. The Neighbor Joining tree based on the concatenated sequence of ITS-trnH-psbA-trnL

\section{cpDNA and $n r D N A$ analysis}

The concatenated sequences of ITS, $\operatorname{trn} H-p s b A$ and trnL comprised approximatively 1058 nucleotides for populations of $P$. elatior and P. leucophylla and 1218 nucleotides for $P$. intricata.

The Neighbor Joining analysis of ITS - cpDNA concatenated sequences differentiates within the sampled populations two major groups: one group composed of $P$. intricata (toghether with Primula veris and $P$. acaulis) and the other composed of P. elatior and P. leucophylla.

The sequences belonging to Primula intricata were highly divergent from the ones shared by Primula elatior group and displayed over 200 variable sites. Between the 2 populations of $P$. intricata, there were found only 6 transitions, something to be expected when we are dealing with two remote populations from two mountain chains with geological structure and glaciation history different from each other (Ronikier et al., 2008; Puşcaş et al., 2008).

Despite the split of Primula elatior group into two, the $\mathrm{NJ}$ tree generated from the cumulative data grouped apart the populations of Primula intricata, thus once again confirming the separation of Primula intricata from the Primula elatior group (Fig. 4).

\section{Conclusions}

This study is the first to use molecular markers such as DNA sequence data from the plastid and nuclear genomes together with AFLP fingerprinting data to determine the phylogenetic position of Primula intricata within the Primula elatior group. To date, Primula intricata was ascribed to the mentioned group, based on the resemblance of morphological characters, but no genetic studies have been performed so far. The genetic analyses (the high number of private fragments, the branch lengths and the high bootstrap support of both the NJ tree, the PCoA dif- ferentiation) stand for a clear separation of Primula intricata out of the Primula elatior group.

\section{Acknowledgments}

The authors are thankful to the Ministry of Education, Research and Innovation, which supported the present study through the program IDEAS (NP-II-ID PCE_2007-1), as a part of the National Research, Development and Innovation Plan for the period 2007-2013 referred to as the National Plan II (NP II). The number and the title of the project are: $405 / 1.10 .2007 /$ "Clarifying the taxonomical position of certain Carpathians-Balkan plant species through morpho-ecological and molecular biology methods". The authors also wish to thank for the partial financial support provided from programs co-financed by The Sectoral Operational Programme Human Resources Development, Contract POSDRU 6/1.5/S/3 - „Doctoral studies: through science towards society". We are grateful to Andreas Tribsch, Peter Schönswetter and Božo Frajman for their valuable help in collecting the samples from the Alps. Also we would like to thank to Michał Ronikier for his help in sampling the population from Western Carpathians.

\section{References}

Bonin A, Bellemain E, Bronken Eidesen P, Pompanon F, Brochmann C, Taberlet P (2004). How to track and assess genotyping errors in population genetics studies. Mol Ecol 13:3261-3273.

Doyle JJ, Doyle JL (1987). A rapid DNA isolation procedure for small quantities of fresh leaf tissue. Phytoche Bull 19:11-15.

Ehrich D (2006). AFLPdat: a collection of $\mathrm{R}$ functions for convenient handling of AFLP data. Mol Ecol Notes 6:603 604 . 
Excoffier L, Lischer HEL (2010). Arlequin suite ver 3.5: A new series of programs to perform population genetics analyses under Linux and Windows. Mol Ecol Res 10:564-567.

Foggi B, Gherardi ME, Signorini MA, Rossi G, Bruschi P (2006). Festuca inops and Festuca gracilior (Poaceae): are they two different species? Bot J Linn Soc151:239-258.

Grenier JCM, Godron DA (1853). France Flora, or Description of Plants that Naturally Grow in France and Corsica, J.B. Baillière, Paris (in French).

Hall TA (1999). BioEdit: a user-friendly biological sequence alignment editor and analysis program for Windows 95/98/ NT. Nucleic Acids Symp Ser 41:95-98.

Huson DH, Bryant D (2006). Application of phylogenetic networks in evolutionary studies. Mol Biol Evol 23(2):254267.

Ishida TA, Hattori K, Sato H, Kimura MT (2003). Differentiation and hybridization between Quercus crispula and Q. dentata (Fagaceae): insights from morphological traits, amplified fragment length polymorphism markers, and leafminer composition. Am J Bot 90(5):769-776.

Jaccard P (1901). Distribution of the alpine flora in the basin of Dranses and in several neighboring areas. Bul Soc Vaud Sci Nat 37:241-272 (in French).

Jacquemyn H, Vandepitte K, Rolda 'n-Ruiz I, Honnay O (2009). Rapid loss of genetic variation in a founding population of Primula elatior (Primulaceae) after colonization. Ann Bot 103:777-783.

Kimura M (1980). A simple method for estimating evolutionary rates of base substitutions through comparative studies of nucleotide sequences. J Mol Evol 16(2):111-120.

Lihová J, Marhold K, Tribsch A, Stuessy TF (2004). Morphometric and AFLP re-evaluation of tetraploid Cardamine amara (Brassicaceae) in the Mediterranean. System Bot 29(1):134-146.

Lüdi W (1927). Fam. Primulaceae. In: Hegi G (Ed.). The Illustrate Flora of Central Europe, München (in German).

Manoko LK, Van den Berg RG, Feron RMC, Van der Weerden GM, Mariani C (2007). AFLP markers support separation of Solanum nodiflorum from Solanum americanum sensu stricto (Solanaceae). Plant Systemat Evol 267:1-11.

Muratović E, Bogunić F, Šoljan D, Siljak-Yakovlev S (2005). Does Lilium bosniacum merit species rank? A classical and molecular-cytogenetic analysis. Plant Systemat Evol 252:97109.

Nei M, Li WH (1979). Mathematical model for studying genetic variation in terms of restriction endonuclease. Proc Nat Acad Scie USA 76:5269-5273.

Nei M (1987). Molecular Evolutionary Genetics. Columbia University Press, New York.

Pax F, Knuth R. (1889). Primulaceae. In: Engler A (Ed.). The Plant Kingdom Regni vegetabilis Conspectus, 10, Leipzig (in German).
Puşcaş M, Choler P, Tribsch A, Gielly L, Rioux D, Gaudeul M, Taberlet P (2008). Post-glacial history of the dominant alpine sedge Carex curvula in the European Alpine System inferred from nuclear and chloroplast markers. Mol Ecol 17:2417-2429.

Ronikier M, Cieślak E, Korbecka G (2008). High genetic differentiation in the alpine plant Campanula alpina Jacq. (Campanulaceae): evidence for glacial survival in several Carpathian regions and long-term isolation between the Carpathians and the Alps. Mol Ecol 17(7):1763-1775.

Smith WW, Fletcher HR (1946). The genus Primula: section Vernales Pax. Transact Royal Soc Edinburgh 34:432-458.

Schönswetter P, Tribsch A, Niklfeld H (2004). Amplified Fragment Length Polymorphism (AFLP) reveals no genetic divergence of the Eastern Alpine endemic Oxytropis campestris subsp. tiroliensis (Fabaceae) from widespread subsp. campestris. Plant Systemat Evol 244:245-255.

Schönswetter P, Tribsch A (2005). Vicariance and dispersal in the alpine perennial Bupleurum stellatum L. (Apiaceae). Taxon 54:725-732.

Schönswetter, P, Solstad H, García PE, Elven R (2009). A combined molecular and morphological approach to the taxonomically intricate European mountain plant Papaver alpinum s.l. (Papaveraceae)-taxa or informal phylogeographical groups? Taxon 58(4):1326-1343.

Shaw J, Lickey EB, Beck JT, Farmer SB, Liu WL, Miller J, Siripun KC, Winder CT, Schilling EE, Small RL (2005). The tortoise and the hare II: relative utility of 21 noncoding chloroplast DNA sequences for phylogenetic analysis. Am J Bot 92(1):142-166.

Taberlet P, Gielly L, Pautou G, Bouvet J (1991). Universal primers for amplification of 3 noncoding regions of chloroplast DNA. Plant Mol Biol 17:1105-1109.

Tamura K, Dudley J, Nei M, Kumar S (2007). MEGA4: Molecular Evolutionary Genetics Analysis (MEGA) software version 4.0. Mol Biol Evol 24:1596-1599.

Thioulouse J, Chessel D, Dolédec S, Olivier JM (1997). ADE-4: a multivariate analysis and graphical display software. Statist Comput 7:75-83.

Valentine DH, Kress A (1972). Primula L. In: Tutin TG, Heywood VH, Burges NA, Moore DM, Valentine DH, Walters SM, Webb DA (Eds.). Flora Europaea, 3, University Press, Cambridge.

Vos P, R Hogers, Bleeker M, Reijans M, van de Lee T, Hornes M, Frijters A, Pot J, Peleman J, Kuiper M, Zabeau M (1995). AFLP: a new technique for DNA fingerprinting. Nuc Acids Res 23(21):4407-4414.

White TJ, Bruns T, Lee S, Taylor JW (1990). Amplification and direct sequencing of fungal ribosomal RNA genes for phylogenetics, p. 315-322. In: Innis MA, Gelfand DH, Sninsky JJ, White TJ (Eds.). PCR Protocols: A Guide to Methods and Applications. Academic Press, Inc., New York. 